\title{
Holistic Ministry based on the Synoptic Gospels and Relevance to Contemporary Generation
}

\author{
Matius I. Totok Dwikoryanto, Muner Daliman, Hana Suparti, and Paulus Sentot Purwoko
}

\section{ABSTRACT}

Holistic service for youth and youth is the basic thing today because youth and youth are the present generation for the future of the church. By using descriptive qualitative methods, it can be concluded that the holistic ministry for youth and youth carried out by church leaders is able to build today's generation that continues to have an impact on the world and is also expected to bring Christian education that has one clear and definite goal/direction, namely knowing, loving, believe in, obey and serve God according to His will and plan and for His glory.

Keywords: Contemporary Generation, Holistic, Ministry, Synoptic Bible.

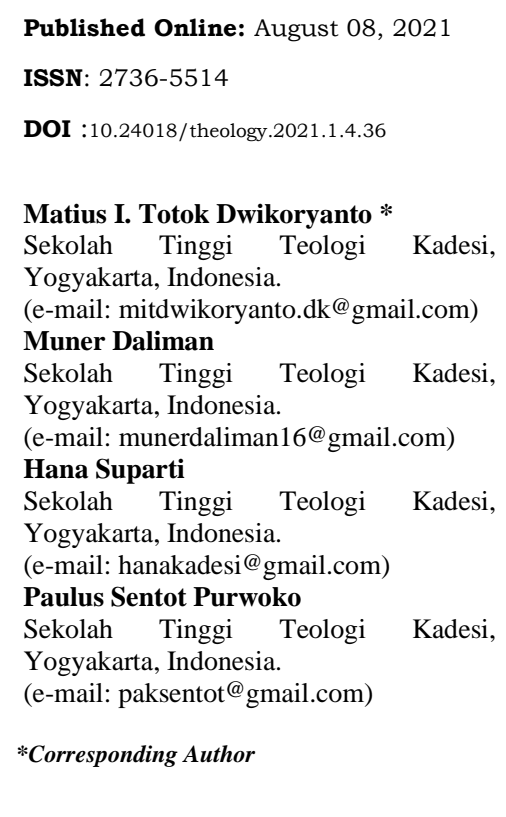

day they reach a mature faith and pay attention to their needs by providing holistic service [3, p. 120]. Especially for children aged 14 to 19 years, because that is the age where children begin to grow from teenagers to adults and are ready to grow into spiritual leaders. At the same time - a period of risk because the child enters the puberty phase where the emotional tendency is more unstable. The period of adolescent development is also the stage of puberty. The stage of puberty (puberty) is a period in which physical maturity takes place rapidly, which involves hormonal and bodily changes, which mainly take place in early adolescence [4, p. 40]. Therefore, the author describes the holistic ministry in the synoptic gospels in this writing in order to provide an understanding for believers to bring youth and youth to become people who love God.

\section{METHOD OF WRITING}

The method in this study uses descriptive qualitative research methods [5], with a literature study approach, the author examines from the discussion of holistic ministry based on the synoptic gospels. This research uses the Bible as the main source in discussing and describing the Holistic ministry. The author also uses reference and reference sources that can complement this research which is still considered a supporting source. The author also immediately uses several additional sources from books that 
discuss about social media and the role of believers in actualizing their faith. The author also uses additional sources from various journal sources.

\section{RESUlT AND DISCUSSION}

The Bible is the content of God's heart that is poured out in writing to humans with the aim that humans can understand and understand correctly about God's care and love that never ends in human life. In the Gospel of Matthew, Mark and Luke are referred to as the Synoptic Gospels because they are known for the element of similarity in the stories written in the three Gospels. There are only three gospels called the Synoptic Gospels, namely: Matthew, Mark, and Luke. For this reason, the author pours Holistic Ministry based on the Synoptic Gospels among Youth and Youth Service. What is recorded in the study of theory in holistic ministry in the synoptic book.

\section{The Ensential of Holistic Ministry}

Ministry can basically be defined as the activities of a person, group, or organization either directly or indirectly to meet needs [6, p. 74]. Ministry is the process of meeting needs through the activities of others directly [7, p. 5]. Moreover, the responsibility to serve is not only entrusted to special people such as pastors, elders, or deacons, but starts from the congregation who are called to serve because of their faith in God and their response to becoming a Christian [8, p. 35].

The basis of the first ministry is the initiative of God, God who works and dirty His hands to create (serve humans). Then God gave orders to humans to cultivate the garden and take care of it, God was giving orders to humans to serve God through His commands. Thus service is the command and will of God. In this command, God is also present and with humans. The glory of God radiates through man. Service is not just an order, but there is also an intimate relationship between humans and God.

While the word 'holistic' comes from the word "whole" (English) which means: whole, completely of an organism" [6, p. 542]. The term holistic ministry is currently widely used by various groups to indicate the form of service, but there are also groups of people who misinterpret it. There is often a misunderstanding about holistic ministry is the assumption that holistic ministries are services in the form of social services, so that in the end there are those who mean that holistic ministries are social services.

The understanding of a holistic ministry is as a ministry that includes preaching the gospel both verbally and in action and is aimed at reaching the whole human being as well, namely humans consisting of body, soul and spirit, and humans who have social, cultural, economic, law and politics with the environment [1, p. 123]. Holistic ministry which includes service elements: Koinonia (fellowship), Martyria (witness), and Diakonia (social service), is an absolute thing that underlines evangelism and brings shalom (peace, salvation) promised by God [9, p. 45]. A holistic ministry which can be described as a "whole one" which has an integral unity with complete aspects. Evangelism touches basic ministry aspects in four holistic ministry dimensions, namely: Fellowship (koinoneo), Ministry (diakoneo), Testimony (martureo) and Preaching (kerigma/kerusso) [2, p. 65].

Holistic ministry aims at the welfare of the whole human being, meaning to preach the full gospel to a whole human being in various dimensions. Therefore, holistic ministry must pay attention to all of these dimensions, namely spiritual, psychological and physical human beings. Holistic ministry seeks to restore balance and harmony between the individual and social dimensions of human beings. Therefore, in holistic ministry, there is no dichotomy or separation between individual and social human needs.

\section{A. The Ensential of Contemporary Youth Generation}

Adolescence is a period of transition or transition from childhood to adulthood. The period in which individuals in the process of growth (especially physical growth) have reached maturity, they no longer want to be treated as children, but they have not reached full maturity and have not entered the stage of adult development. Negatively, this period is also called the "unbalanced" or unbalanced, unstable, and unpredictable period. In this period there were changes both in terms of psychological, social and intellectual [10, p. 52].

Adolescence or ages $12-22$ is a period of transition between childhood and adulthood. During this period of development, adolescents reach physical, mental, social and emotional maturity [11, p. 12]. Several studies on physical growth in adolescents show that height growth in adolescence is faster than in previous periods, and changes in body proportions in female adolescents occur more rapidly than in male adolescents. 12,13 or 14 years girls are taller than boys [12, p. 66]. The period of adolescent development is also the stage of puberty. The stage of puberty (puberty) is a period in which physical maturity takes place rapidly, which involves hormonal and bodily changes, which mainly take place in early adolescence [12, p. 404].

Adolescents in the stages of cognitive development enter the formal operational stage. This formal operational stage is experienced by children aged 11 years and over. At this formal operational stage, the child has been able to realize a whole in his work which is the result of logical thinking. The emotional and moral aspects have also developed." [11, p. 72]. According to Piaget, in this stage adolescents begin to interact with the environment and are wider than the stages of children, adolescents begin to interact with their peers and even try to be able to interact with adults. Because at this stage children have begun to be able to develop their normal thoughts, they are also able to achieve logic and reason and can use abstraction. They can understand the symbolic and figurative meaning. Involving them in an activity will have a more positive impact on their cognitive development [12, p. 76]. Therefore, a mentor is required to be pro-active, creative and innovative in directing youth. For that, what should be done in a holistic service for youth and youth.

\section{B. Holistic Ministry in the Physical Needs}

One of the emphasis in the holistic ministry performed by the Lord Jesus is physical ministry. Because physical needs 
are the basic requirements of life for living things, especially humans, humans need air, food, water, clothing, and shelter to survive, besides that humans also have a need for recreation, education, and entertainment. The need is something that must be fulfilled for living things to carry out their lives as a goal for survival. So, that in this life, humans cannot be separated from activities to fulfill their basic needs. This physical ministry is also the focus of holistic ministry. This ministry focuses on physical service to youth and youth. Everyone has their own and different needs in life. Differences in human needs are influenced by many factors, for example, economic factors. These needs become wants when directed to certain objects that can satisfy those needs. Human needs themselves consist of primary, secondary and tertiary needs, primary needs are the most basic needs that humans must fulfill to maintain their lives such as food, clothing, shelter [13, p. 33].

A person whose needs are not met in general will make various efforts to meet his physiological needs first. For example, a person who lacks food, safety, and love will usually seek food first instead of looking for love. Because physiological needs are essential for survival [14, p. 4]. Children's physical, mental, and emotional states are unique and special and therefore require special attention in serving them. On the other hand, the source of Christian ministry, namely the Bible, was written for adults. Lawrence O. Richard says: "The bible really is an adult book, written by adults and for adults." [5, p. 270]. Which explicitly states that the Bible is truly an adult book, written by adults and for adults. Therefore, it takes the seriousness of the church to serve and teach children.

\section{Holistic Ministry in of the Basic Human Needs}

In Matthew 14:16 and Matthew 25:36. This verse tells of an incident where many people were enthusiastic and wanted to hear about Jesus' preaching so that they followed Him wherever He went until one day it was getting dark and Jesus' disciples took the initiative to send the crowds away. But the astonishing thing that Jesus did was not to let them go but to require His disciples to feed them all. Feeding in the context of this verse the word "Phago" is used which means physical food / food that fills the stomach. This word is not a figurative word to describe spiritual food that satisfies the soul / spirit but food that is eaten every day to fill the stomach. Because the Lord Jesus was moved by compassion. Remembering that mercy is derived from God so that in controlling the earth, managing the earth, carrying out the divine mandate, humans use their love so as to create harmony and peace. Likewise, in His ministry Jesus based on compassion showing empathy for those who enthusiastically followed Him.

Love and care are one of the basic human needs. Bill Wilson, a church planter, wrote in his book, "Church members are easily reached through positive and loving relationships." [16, p. 95]. Thus the ministry of Jesus those who are lost will be easy to reach if touched with substantial things in their lives, namely about their basic needs. The outpouring of love for the congregation is a shared responsibility to mold them into a congregation that occurs naturally and quietly in the church. This is realized because each member of the congregation takes the time to get to know each other as a family [17, p. 32]. Because holistic attention is an indispensable component for the growth and development of the congregation, especially the development of emotional health and the formation of the personality of believers. So that from the actions that Jesus did, there were more than 5000 people who were touched by the love of Christ so that they were more enthusiastic in accompanying Jesus' servants. Because "Love is the thing that is most easily felt by every member of the church that cannot be replaced with material things" [18, p. 29].

Likewise, clothing continues to develop along with the influence of culture, function, and fashion [19, p. 2]. Clothing not only serves as a protective device for the human body, but also as a tool to increase self-confidence for the wearer. However, there is a dress code that is very important in the life of a Christian. Why, because ethics is moral and moral. Ethics concerns the way an act must be done by humans and concerns an act that can be done or not [20, p. 9]. Ethics regulates human behavior normatively, meaning that it provides norms for human behavior and thus states what to do or not to do. Ethics are principles of right and wrong conduct. The basis for doing what is right and the discernment for seeing what is right, are fundamental throughout the Bible [21, p. 94]. Clothing and appearance are the most powerful nonverbal communicators not only of socioeconomic status, but also of moral values. According to Christianity, what should be contemplated in dressing is showing Christian values that have been applied to others through outward appearance. Christianity also emphasizes the principles of dress and adornment that must be followed because outward appearance will testify, whether visible or not, of God's relationship [22, p. 17]. It is important for youth and youth in bringing this education to be considered as part of a holistic ministry for them.

\section{Holistic Ministry to Heal the Sick Peoples}

In Mark 7:32-35, that there is One of the emphasis in the physical ministry of Jesus is how Jesus treats and heals sick people. Pain is because a person experiences in his body a disorder / found dysfunction of the body's organs. Pain contains a biopsychosocial dimension, namely disease, illness, and sickness [23, p. 22]. Disease is a biological dimension, where symptoms are known through medical diagnosis. Illness is a psychological dimension, which is a person's subjective experience of illness (discomfort). In general, disease is detected when it causes changes in metabolism or causes cell division that causes signs and symptoms to appear. The Bible gives an explanation that the causes of illness, which exist because the relationship with God is cut off, he lives outside of fellowship with God [24, p. 41]. All diseases show human weakness that can bring suffering or disease that can lead to death if no healing or treatment is carried out. The healing referred to here is healing from God or the strong power of God in the Holy Spirit, which can also be done through human intervention, meaning that humans can be used by God as a tool or channel, where they can function if God allows because it is the actual healing so that they become healthy. [25, p. 21].

Healing people can not only be done by the Lord Jesus, but His disciples were also given the power to eliminate sickness. God 's power which is moved by faith is able to 
make the miracle of healing happen . Without faith in God, miracles are impossible. According to J. Wsley Brill there are three things about faith. First, belief that comes from knowledge (Psalm 9:11; Romans 10:17). Second, belief so that it recognizes the truth (Mark 12:32). Third, belief so act to apply for oneself, John $1: 12 ; 2 ; 24$. The word faith comes from the Greek 'Pisteo', which means 'I believe'. The understanding of faith taught by the Bible is different from the understanding of faith from other religions. Christian faith is supernatural. The Christian faith allows us to believe things that seem "unreasonable". Take, for example, the miracles that the Bible tells of. For people who do not believe, it is very unreasonable and counter to the ratio. But for people who believe, these miracles can be accepted by reason or ratio because of faith [26, p. 80]. Christian faith can be defined as a life lived in response to the kingdom of God in Jesus Christ so that the value of the kingdom of God appears [27, p. 82].

Healing at this time is not only limited by divine power but can also be done by other means, for example through medical medicine. This means that medical science is second-class, or prayer is also second-class, but for believers God-given healing can also be through the mediation of medical knowledge as well as a service to Christ, where for believers the knowledge becomes transparent (he is used by God to bestow his gift [24, p. 120]. In the visit there should be more primary and very important relationships between people who are concerned. So counseling is not nothing more than a relationship but there is more to it. Pastoral counseling services that really want to produce a process of liberation are pastoral services that deal with concrete problems of human life [28, p. 52].

The orientation of pastoral care can be seen from the following activities [29, p. 22]: first, search and visit. Pastoral is a ministry that is done to find and visit the congregation. Second, one by one. Pastoral is a ministry aimed at members of the congregation one by one or individual ministry, especially those who are experiencing life's struggles. Third, are struggling. Pastoral care is a ministry given to a congregation that is struggling. Fourth, the Word of God. Pastoral is a ministry given to preach the word of God to the congregation who is struggling. Fifth, Faith is a strong belief and belief in a God who is powerful, great and mighty, and who is able to save and free from the bondage of $\sin$.

William A. Clebsch and Charles R. Jaekle in their book entitled Pastoral Care in Historical Perspectives state that traditionally there are four functions of visits, namely [30, p. 85]: First, the healing function, which is a pastoral function that aims to overcome some damage by returning the person to a whole and leading him to a better direction than his previous condition. Second, the function of guiding (guiding), that is, helping people who are in confusion to make definite choices among alternative thoughts and actions, if such choices are seen as affecting the state of their soul now and in the future. Third, the function of sustaining (sustaining), which is helping people who are injured (ill) to survive and get through a situation in which recovery to its original condition or healing from an illness where there is no hope of recovery. Fourth, the function of reconciling/repairing relationships (reconciling), which is an effort to rebuild damaged relationships between humans and God and each other.

\section{E. Pelayanan Holistik Membantu dalam kemiskinan}

Mark 14:7a for you are always with the poor, and you can help them whenever you want. The Lord Jesus gave a direction to His disciples to see and empathize with the poor. The Lord Jesus showed that one form of holistic physical ministry is not only focusing on oneself or a group but also on people who are less fortunate financially or commonly called the poor. It is undeniable that poverty is one of the main problems experienced by all nations in the world at all times. The problem of poverty is still the biggest problem in the world today, because it involves a person's life and death problem. According to a 2003 report from the United Nations Development Program (UNDP), there are 113 million school-age children, who are not in school and 95 percent of them are poor children [31, p.23].

There are people who think that poverty is a matter of material, about clothing, food, shelter. There are also those who spiritualize this term, namely poor souls, namely people who feel inferior, helpless [32, p. 80]. There are also those who see that poverty is essentially too much interference from the authorities against the poor, especially rural communities. There are also those who view that poverty is basically a matter of cultural poverty, namely the mentality of society which is influenced by certain cultural values such as surrender, fate, and destiny [33, p. 43]. So, actually the term poverty is a relative term, meaning from which perspective the problem of poverty is to be seen. Poverty is a condition where a person or group of people is unable to fulfill the basic needs of life as a human being. The basic needs of life are always understood as the needs of clothing, food, shelter, and rear, plus health and education.

Conrad Boerma notes that the first word used to describe the poor is "ani." The literal meaning of the word ani is a person who stoops, who lives in a low state and he must look up, when dealing with people of a higher position [34, p. 11]. The word is used to compare them with a group of rich people. So, the existence of the poor group was a victim of the social structure at that time. The rich group that treats the poor as people from the lower classes. Their social rights are also reduced. Because they are poor, they become despicable people, worthless in the society of the rich. Poverty is experienced as an extortion of their rights to life. From this glimpse we can see that "even poverty in the Bible is directly related to the structures in which people live" [34, p. 23]. It must also be admitted that poverty can also be caused by the laziness of the poor themselves. For this reason, being critical of the nature of laziness is not uncommon in the book of Proverbs (Proverbs 10: 4, 20: 13).

Another word to refer to people who are in material need is the word "dal". The word is used to refer to those who are in an unfavorable position such as workers who live in rural areas $[34$, p. 33]. In addition to these two words there is also the word "Ebyon". This word is used to refer to those whose lives depend solely on the mercy of others. They are a group of beggars, they beg because of their physical limitations such as lame and paralyzed The Bible writers used several terms to describe what poverty is. Some describe it as 
someone who wants and needs something. They are people who are weak and helpless, people who are bent over, who are trampled and squeezed by others, who are lowly who carry heavy burdens [35, p. 20]. Among you poor are widows, orphans and foreigners.

Whereas in the New Testament, poor people, people who have nothing, who struggle to overcome their suffering in order to maintain a longer life. The term most often used to describe the condition of the poor as mentioned above is "Ptochos." [36, p. 2]. Those who are called ptochos are those who can be categorized in the absolute poverty group. Ptochos is a term for those who are truly destitute, truly destitute and it is the same with beggars.

\section{SPIRITUAL MINISTRY}

The emphasis of the Holistic ministry that the Lord Jesus did in his ministry was related to spiritual/spiritual service. Because humans have spiritual needs that must be met. This relates to the psychology of each person, so that spiritual needs are not physical itself, but the deepest human soul. One of the activities carried out to meet their spiritual needs is to worship. Worship includes all actions that are not limited to the profession of faith, but all actions that are intended to serve God.

Because humans are created from two elements, namely with material (Body) and non-Material (Soul, Spirit) parts, God thus concludes His work with a "personal touch". God formed man from the dust of the ground and gave him life by breathing out His own breath (Genesis 2:7) so that man could live. Kevin J. Corner describes the part of the spirit as follows: Spirit is the part of man that was given by God to sustain life and give man intellectual, energy and character. $\mathrm{He}$ is also the God-conscious part of man capable of knowing who God is. When God created man, He created a spirit in man. The Spirit comes from God, resides in the individual and will return to God at death. The Spirit is part of an eternal human being who can worship God who is also a Spirit (John 4:24). When man falls into sin, his spirit loses contact with God. And that can only be renewed by the restoration of the soul through repentance [37, p. 56].

The word spiritual also means spiritual has the root word spirit which means spirit. This word comes from the Latin Spiritus which means breath, besides the word spiritus can mean a form of alcohol that can be purified. So spiritual can be interpreted as something pure. Our true self is our spirit. Spirit can be defined as the life energy that enables us to live, breathe and move. Spirituality also means everything outside the human physical body, including thoughts, feelings, actions, and character [38, p. 20]. Spirituality is related to the life of faith i.e. what drives and motivates it and what people feel can help to perpetuate and develop it. [39, p. 32]. Spirituality is a quality that is achieved by human effort and spirituality is also an effort to develop human capacity [40, p. 48]. Service must be manifested in the form of an attitude that does not regard the "servant" as higher or lower than the people being served as the servant of Christ [41, p. 51].

\section{A. Faith Teaching Foundation}

Matthew 17:20 He said to them, "Because you do not believe. For truly I say to you, if you had faith the size of a mustard seed, you could say to this mountain, Move from this place to there, and this mountain will move, and nothing will be impossible for you. The holistic ministry that Jesus did in fulfilling the spiritual needs of believers is the cultivation of faith. The word unity of faith in this verse is used the word "pistis" which means truth or not only refers to one mind but also has a deeper belief which is an inseparable unity, namely salvation in Christ.

Faith is an important basis for believers in doing all things. Faith is the basis of all that we hope for and the evidence of all that we do not see. This foundation and belief is the word of God (Hebrews 11:1)(Brill, 2000, p. 40). Without faith in God, it is impossible for what we are doing today. According to J. Wsley Brill there are three things about faith. First, belief that comes from knowledge (Psalm 9:11; Romans 10:17). Second, belief so that it recognizes the truth (Mark 12:32). Third, belief so act to apply for oneself, John $1: 12 ; 2 ; 24$. The word faith comes from the Greek 'Pisteo', which means 'I believe'. The understanding of faith taught by the Bible is different from the understanding of faith from other religions. Christian faith is supernatural. The Christian faith allows us to believe things that seem "unreasonable". Take for example the miracles that the Bible tells of. For people who do not believe, it is very unreasonable and counter to the ratio. But for people who believe, these miracles can be accepted by reason or ratio because of faith [26, p. 75]. Christian faith is a life lived in response to the kingdom of God in Jesus Christ [27, p. 66]. According to Jehoshaphat's observations, there are three elements contained in the word 'belief', namely acknowledging and believing in the existence of God, that God really exists and accepting without doubt that God really exists [26, p. 75]. The Christian faith requires that in it there is a belief and belief in the truths that are recognized as the essence of the Christian faith [27, p. 72].

Having faith is not just believing in a number of doctrines, but also believing in someone who is trusted. In Latin, faith is called fidera which means "to believe or believe in oneself" if the activity of trusting is more focused on the cognitive dimension, then the activity of believing is more focused on the affective dimension. This affective dimension of the Christian faith takes the form of a trusting relationship with, and belief in, a personal God who saves through Jesus Christ [27, p. 74]. Actually, the word Trust is more of a humble attitude to trust God. "Trust" or trust is an attitude of the heart of the mind that entrusts life to a person who is trusted, honest, and has no evil intentions [42, p. 25]. Just as J. Wsley Brill said that faith or trust in God means relying on Him, and getting support from Him [42, p. 25]. For this reason, Jesus gave teachings about faith to each of His disciples so that they could still rely on and fully hope in God.

\section{B. Holistis Ministry and Educational Ministry}

Matthew 26:20 After nightfall, Jesus sat down to eat with the twelve disciples. In His ministry, the Lord Jesus often invites His disciples to gather together in fellowship with the Lord Jesus, which consists of 12 core disciples. This is so that each student can directly interact with the teacher and have a personal closeness with the teacher. This habituation 
is carried out by the Lord Jesus every time in a place that is possible. So that they can more intensely understand and understand the vision and mission of the Lord Jesus.

The fellowship of the church is built on the foundation of the ministry performed by Jesus Christ. Therefore, the definition of the word Church comes from the Portuguese "Igreya" which means the fellowship of believers [43, p. 24]. The relationship between having fellowship with the Lord Jesus as a real teacher is teaching students to have one heart in receiving learning, teaching students to obey everything that is ordered by the teacher besides that students can follow Christ's example in gathering disciples making them loyal followers and have renewal behavior, become a wise person like the image of Christ who leads to the perfection of life. Thus, equipping them in the context of character education [44, p. 62].

According to Jean "adolescents in the stages of cognitive development enter the formal operational stage. This formal operational stage is experienced by children aged 11 years and over. At this formal operational stage, the child has been able to realize a whole in his work which is the result of logical thinking. The emotional and moral aspects have also developed." [45, p. 59]. According to Piaget, in this stage adolescents begin to interact with the environment and are wider than the stages of children, adolescents begin to interact with their peers and even try to be able to interact with adults. Because at this stage children have begun to be able to develop their normal thoughts, they are also able to achieve logic and reason and can use abstraction. They can understand the symbolic and figurative meaning. Involving them in an activity will have a more positive impact on their cognitive development. Therefore, a mentor is required to be pro-active, creative and innovative in directing youth.

The word worship actually comes from the vocabulary "äbodah" (Hebrew) or worship (Arabic) which literally means devotion, respect, homage, an "attitude and activity" that recognizes and respects someone (or the divine) [46, p. 44]. Or it can also be said to be a respect for life that includes piety (which is regulated in a procedure), the implications of which appear in the behavior and activities of daily life [47, p. 87]. So, worship here is an expression and attitude of life that is full of devotion (surrender) to the Divine, whose influence is seen in right behavior. Worship is also related to religious obligations, namely God's commandments (Deuteronomy 11:8-11). So, in essence worship is not only the implementation of religious ceremonies in places of worship, but includes the implementation of religious obligations, such as: circumcision, fasting, Sabbath observance, the law and prayer. Thus, worship must also contain meaning for moral life [48, p. 12].

Evangelism touches basic ministry aspects in four holistic dimensions of ministry, namely: fellowship (koinoneo), ministry (diakoneo), testimony (martureo) but these three things are still incomplete if there is no teaching (Didaskalia)" [2, p. 52]. Many churches forget teaching/education in the church. The church focuses on the 3 tasks of the church and puts aside education in the church. Even the Lord Jesus specifically gave the command in Matthew 28:20a and teach them to do everything that I have commanded you. This emphasizes that education is a fundamental mandate that must be carried out.

The teaching that is meant by the great commission begins with this statement of the Lord Jesus, the implementation of this teaching must aim to help humans build their lives on a solid foundation, namely the Bible, the Word of God. This is the mission of Christian education. Organizing an educational process that helps every student to be able to build a house of their life that can stand firm in the midst of this era, and last for eternity. This is in line with the opinion of Robert W. Pazmino, he formulated Christian teaching as follows: Christian education is a divine and human effort that is carried out systematically and continuously, to transmit knowledge, values, attitudes and skills and behaviors that consistent with the Christian faith. Education seeks change, renewal and reform of individuals, groups and structures, by the power of the Holy Spirit, so that students live according to God's will, as stated by the Bible and by the Lord Jesus Himself [49, p. 81].

The Lord Jesus gave the main mission of organizing Christian Teaching [50, p. 23]. First, so that every student becomes a person who knows the true God in Jesus Christ personally. Second, being a committed disciple of Christ that God is fully sovereign over his personal life covering all aspects. Third, to be a servant of Christ who always walks under the leadership of the Holy Spirit, faithfully obeys God's will according to the Bible's teachings which have full authority in his life. Fourth, to belong to God's beloved, who for life only thinks about things that are holy, pleasing and glorifying God.

\section{Holistic Ministry in Developing Talents}

In Matthew 25:20 relating to developing talents, the attitude and focus of education carried out by the Lord Jesus is to provide teaching to become a responsible people, one of which is by developing the talents that God has entrusted to him. Dianne Bergant and Robert Karris say "talent means natural talent developed by diligent practice" [51, p. 71]. In English it is translated as talent, namely skills or expertise such as those possessed by artists, sculptors, designers which not everyone usually has. When we talk about talent, we tend to think of something special that most people don't have. And talent is solely to satisfy personal desires or ambitions.

In general, talent can be said to be talent which can be said to be a condition in someone that allows him with a special training to achieve a special skill, knowledge, skill. Potential is a style available to a person that allows the development of certain characteristics, this power is present from birth, or is innate [51, p. 44]. The Bible clearly states that every Christian has been given a talent, namely the ability to serve in the community or church (God's people). On the other hand, service is more than self-actualization.

Because ministry is something that is fundamental in the life of the church. Therefore, the responsibility to serve is not only entrusted to special people such as pastors, elders, or deacons, but starts from the congregation who are called to serve because of their faith in God and the response to become a Christian [25, p. 74]. George Barna states that talent development is important for the following reasons: First, because Jesus set the example and commanded it; second, because talent development is needed by the church 
to be healthy and productive; third, Because we cannot reach our potential without spiritual growth; Fourth, because we cannot influence the world unless we can demonstrate a transformation based on faith [52, p. 33]. This is so that he can hone himself to become an experienced servant in sharing knowledge with new believers practically [53, p. 46]. In addition, ministry talent training is a way to equip believers for ministry according to their calling (Ephesians 4:11-16), and to make them sufficiently intelligent and reasonable to answer the expectations they have (1 Peter $3: 15)$ [54, p. 211]. So, it can be concluded that ministry talent training is a process of educating believers with all practical Bible truths to be able to become good stewards.

\section{Entrepreneurship and Educate in Ethict}

Luke 19:23 If so, why don't you give my money to the man who runs the money? So, when I return, I can take it along with the flowers. In addition to developing the talents possessed by every believer in the Lord Jesus, he also teaches how a person can develop himself into an entrepreneur. The word entrepreneur/entrepreneur is not found in the Bible, but the idea and practice of entrepreneurship is witnessed in the Bible. The basis of the entrepreneurial attitude is the word 'image and like'. Because humans are created in the image and similar to God, humans have the ability to be creative and innovative. The narrative text of Genesis 1:27 and 2:15 emphasizes the potential of entrepreneurs and the manifestation of entrepreneurs in humans. God placed humans in the garden of Eden for creativity and innovation, pay attention to the word: nurture and strive in Genesis 2:15. According to Enns, the word image is used in the sense of similarity in spiritual, natural and moral. In human likeness (Adam and Eve) naturally, affirms that humans have reason, emotion, and will to know and communicate with God [55, p. 84]. The ability of ratio, freedom and creativity that exist in humans enable humans to do what is called an entrepreneur (the ability to innovate, be creative and the ability to bear risks/dare to face risks as the characteristics of entrepreneurs). The image of God is a number of abilities needed to manifest this relationship and function. These are the abilities of God which, when reflected in man, enable worship, personal interaction, and work to take place." [56, p. 93].

As Brian Baugus said, "Entrepreneurship is a creative act made possible by the creative impulse that God gives to humans/believers. Moreover, it requires certain personal qualities that God wants believers to possess." [57, p. 5]. A spiritual entrepreneur is a person who has a unique relationship with God as the basis for his strength and integrity in doing business. Spiritual entrepreneurs are distributors of God's blessings to others around them [58, p. 15].

Entrepreneurship refers to a high degree of independence, by which there is a mind, the courage to act and do something independently by using a unique way to bring success, success, or luck. Based on this definition, Tomatala directs the emphasis on independence which is one of the characteristics of entrepreneurship. Based on this focus, the characteristics of an entrepreneur are identified as follows: First, an entrepreneur has independence in superior thinking, namely the ability to think highly to turn something into an opportunity for success or through the ability to think highly. An entrepreneur always strives to seize opportunities, create, and seek opportunities in everything. Second, an entrepreneur has independence in the courage to make decisions and dare to take risks that may arise from his decisions. Third, an entrepreneur has independence in his expertise in engineering superior ways to capture business opportunities [58, p. 17].

\section{E. Holistic Ministry in Ethical Education}

Luke 14:8-11 In this verse there is a message from the Lord Jesus in his teaching ethics to his disciples regarding what to do and how they can position themselves so that they do not become stumbling blocks with others. One of his ethical teachings is related to how a person sits at a wedding party. The Lord Jesus taught them not to sit in the front seats because the front seats are for honorable people. But sit in the chair behind them so they don't get embarrassed. Do not consider yourself more honorable than others but try to be a humble person. Cognitive development is characterized by how children think and grow their faith; Social development by teaching ethics and how children relate to and learn from others; Moral development is characterized by how children understand and integrate moral concepts [59, p. 23]. According to Bertens, ethics has 3 meanings, namely: First, ethics in the sense of values or norms that become a guide for a person or a group of people in regulating their behavior. Second, ethics in the sense of azaz or moral values / code of ethics. Third, ethics in the sense of the science of good and bad [60, p. 27]. Helden and Richard formulate the notion of ethics or morals as a sensitivity in thoughts, feelings, and actions to what is experienced. Its function is to give orientation how one should step in this life hidup [61, p. 44]. That's why the Lord Jesus emphasized that ethical education or teaching is very important for young people to shape their morals and lives according to God's word.

Adolescence is a survival of the stages of life that humans must go through. Given the foregoing, the formation of spiritual morals for teenagers is also very important. "In this case parents must be good leaders, namely leaders who are in the middle" [62, p. 9]. Therefore, the role of parents is very necessary in shaping the ethics of adolescents starting from home to prepare themselves to enter the next stage of life. In addition to spiritual education at home, which is very necessary for teenagers, the church is a second place for teenagers to be educated so that they can grow as a whole/holistic. Here are some suggestions for today's youth coaches: First, youth coaches need a more comprehensive understanding of the personality of teenagers. Second, youth coaches must learn to accept the existence of teenagers as they are. Third, youth coaches need to share their feelings with teenagers because teenagers want to be treated as adults. Fourth, youth coaches need to be role models. Fifth, youth coaches provide guidance to their teenagers in dealing with their physical changes so that teenagers can accept and respect themselves. Sixth, helping youth to understand about the authority that God is above all, but God gave parents and other adults as holders of authority from God. Seventh, equip youth to face challenges, peer pressures and demands of unbelieving groups. Eighth, guiding youth to understand 
the dynamics and nature of love based on the principles of God's Word. Ninth, teaching manners and character apart from building faith [62, p. 77].

\section{F. Ministry in Support and Giving}

In Matthew 14:27-31 there is a teaching in socioemotional ministry, so the first thing that can be done is to provide psychological support to children. Just like what the Lord Jesus did when Peter began to waver because of the circumstances at that time. Jesus said "Calm down, I'm not afraid" this made Peter's confidence increase so He dared to walk on water. The Lord Jesus is providing service in the form of moral support by giving soothing words to build faith so that even Peter can go through it. Because according to psychology, mental/psychic health is also closely related to physical and behavioral health [63, p. 12]. Mental health is a condition in which individuals have visible well-being who are able to realize their own potential, have the ability to cope with the normal stresses of life in various situations in life, are able to work productively and productively, and are able to contribute to their community. Mental health needs to be seen as as important as physical health. Recognizing that health is a state of balance between oneself, others and the environment helps society and individuals understand how to maintain and improve it.

Mental health has a continuum relationship. Mental health and mental illness are determined by various biological, psychological and social factors, such as health and illness in general [63, p. 25]. If viewed from the continuum, mental health that is not considered can develop into mental illness. This situation is relatively permanent but can change over time or the situation experienced by the individual. Individuals who are mentally healthy or have positive mental health are able to deal with various situations in life and can adapt well. Individuals show well-being and feel happiness. One of the characteristics of a mentally healthy individual is having resilience. Resilience is defined as a dynamic process in which individuals demonstrate adaptive functioning in the face of significant adversity [64, p.44].

Mental health in adolescents also involves their capacity to develop in various areas such as biological, cognitive and socio-emotional. Therefore, it is important for youth and adolescents to understand the stages of development as an effort to see indications of problems in adolescent development. Children who have mental health have characteristics that can be observed from the development process. Socio-emotional processes involve changes in emotions, personality, relationships with other people and the social environment [65, p. 77]. A well-developed socioemotional process enables children to be able to recognize, differentiate, manage, and express emotions appropriately. As children develop, they need to become aware of other people and try to cultivate empathy for others.

\section{CONCLUSION}

It can be concluded that the holistic ministry in the Synoptic Gospels plays an important role for the growth of faith and spirituality of Contemporary generation. Therefore, as believers, especially Christian educators, a commitment is needed to help every generation today so that they can undergo a process of growth and knowledge of God in accordance with Bible principles and the will of the Lord Jesus Christ. With a holistic ministry for today's generation, it is hoped that it can bring Christian education that has one clear and definite goal/direction, namely knowing, loving, believing, obeying and serving God according to His will and plan and for His glory.

\section{REFERENCES}

[1] Herlianto. (1998). Pelayanan Perkotaan. Yabina.

[2] Tomatala, Y. (2003). Teologi Misi. YT Leadership Foundation.

[3] E.G. Homrighausen \& I.H. Enklaar. (2007). Pendidikan Agama Kristen. BPK Gunung Mulia.

[4] Jhon W. Santroct. (2011). Life-Span Development: perkembangan masa hidup. Erlangga.

[5] Zaluchu, S. E. (2020). Strategi Penelitian Kualitatif dan Kuantitatif Di Dalam Penelitian Agama. Evangelikal: Jurnal Teologi Injili Dan Pembinaan Warga Jemaat, 4(1), 28-38. https://doi.org/10.46445/ejti.v4i1.167.

[6] Chaniago, A. Y. S. (2002). Kamus lengkap bahasa Indonesia. Bandung: Pustaka Setia.

[7] Moenir. (2006). Manajemen pelayanan umum di Indonesia. Bumi Aksara.

[8] Ch. Abineno. (2002). Garis-Garis Besar Hukum Gereja. BPK Gunung Mulia.

[9] Kuiper, A. de. (2003). Misiologi. BPK Gunung Mulia.

[10] D. Gunarsah, S., \& D. Gunarsah, Y. singgih. (2008). Psikologi Perkembangan Anak Dan Remaja. In PT. BPK Gunung Mulia.

[11] Ali, M. (2012). Psikologi Remaja Perkembangan Peserta didik. PT. Bumi Aksara.

[12] Sulaeman, D. (1995). Psikologi Remaja: dimensi-dimensi perkembangan. Mandar Maju.

[13] Buchari Alma. (2013). Kewirausahaan. Alfabeta.

[14] Wardalisa. (2013). Teori hirarki kebutuhan. Theory Of Abraham Maslow.

[15] Lawrence, O. R. (1998). Creative Bible Teaching. Moody Press.

[16] Bill Wilson. (2012). gereja tanggung jawab Siapakah Ini? Metro Ministry.

[17] Robert J. Keeley. (2009). Menjadikan jemaat Kita Bertumbuh dalam Iman. Andi Offset.

[18] Setiawani, M. G. (1999). Pembaruan Mengajar. Cetakan Kelima Bandung: Yayasan Kalam.

[19] Wasia Roesbani. (1994). Pakaian Pengetahuan. Balai Pustaka.

[20] K. Bertens. (2007). Etika. Gramesia Pustaka.

[21] F. Browning. (2007). Kamus Alkitab. Gunung Mulia.

[22] William Thourlby. (1989). You Are What You Wear. Forbes/Wittenburg \& Brown.

[23] Notosoedirdjo. (2001). Kesehatan mental: Konsep dan penerapan. Universitas Muhammadiyah.

[24] Ch.Abineno. (1992). penyakit dan penyembuhan. BPK Gunung Mulia.

[25] Ch.Abineno. (2000). Karunia Roh Kudus menyembuhkan. BPK Gunung Mulia.

[26] Yosafat. (2014). Integritas Pemimpin Pastoral. Andi Offset.

[27] Nuhamara, D. (2009). Pembimbing PAK, Pendidikan Agama Kristen. Jurnal Info Media.

[28] Gary R. Collins. (1998). Konseling Kristen Yang Efektif. SAAT.

[29] Tulus Tu'U. (2010). Dasar-Dasar Konseling Pastoral Panduan Bagi Pelayanan Konseling Gereja. Andi Offset.

[30] William A. Clebsch. (2002). Pastoral Care in Historical Perspective. Gandum mas.

[31] Hartono Budi. (2003). Teologi, Pendidikan, Pembebasan. Kanisius.

[32] Malcolm B. (1997). Tugas Manusia Dalam Dunia Milik Tuhan. BPK Gunung Mulia.

[33] awan setya dewanta. (2000). Kemiskinan dan Kesenjangan di Indonesia. Aditya Media.

[34] Conrad Boerma. (2007). Dapatkan Orang Kaya masuk Sorga? BPK Gunung Mulia.

[35] Yosef P. Widyatmadja. (2010). Yesus \& Wong Cilik: Praksis Diakonia Transformatif dan Teologi Rakyat di Indoensia. BPK Gunung Mulia.

[36] Wolfgang Stegemann. (1994). Injil dan Orang-orang Miskin. BPK Gunung Mulia.

[37] Kevin J. Corner. (1991). Doktrin Dasar I. Harvest Publication.

[38] Prijoksono \& Erningpraja. (2003). Spiritualitas dan Kualitas Hidup. Gramesia Pustaka. 
[39] Alister E. McGrath. (2007). Spiritualitas Kristen. Bina Media Perintis.

[40] Einar M. Sitompul. (2014). Perjalanan Sarat Muatan. UPI STT Jakarta.

[41] Retnowati. (2018). Teologi Kepemimpinan dan Manajemen (F. T. UKSW (ed.)).

[42] Brill, W. (2000). Dasar yang teguh. Kalam Hidup.

[43] B. S. Sijabat. (2004). Strategi Pendidikan Kristen. Andi Offset.

[44] GP, Harianto. (2012). Pendidikan Agama Kristen dalam Alkitab dan dunia Pendidikan Masa kini. Penerbit Andi.

[45] D, Y. S., \& Sutantoputri, N. W. (2009). Hubungan Orang Tua dan Remaja. In S. D. Gunarsa (Ed.), Dari Anak Sampai Usia Lanjut Bunga Rampai Psikologi Perkembangan (3rd ed.). BPK Gunung Mulia.

[46] G. Johannes Botterweck Helmer Ringgren. (1997). heological Dictionary of the Old Testament, vol 1. Company Grand Rapids.

[47] Ray C Stedman. (2010). Petualangan Menjelajari Perjanjian Lama Dari Tulisan Asli. Duta Harapan Dunia.

[48] James F. White. (2005). Pengantar Ibadah Kristen. BPK Gunung Mulia.

[49] James F. White. (2005). Pengantar Ibadah Kristen. BPK Gunung Mulia.

[50] Samuel Sidjabat. (2004). Strategi Pendidikan Kristen. Andi Offset.

[51] Dianne Bergan. (2002). Tafsiran Alkitab Perjanjian Baru. Kanisius.

[52] Peter Wagner. (1996). Strategi Perkembangan Gereja. Gandum mas.
[53] Paul D. Stanley dan J. Robert Clinton. (2004). Mentor: Anda Perlu Mentor dan Bersedia Menjadi Mentor. Gandum mas.

[54] Peters, G. W. (2013). Teologi Pertumbuhan Gereja. Gandum Mas.

[55] Paul Enns. (2008). The Moody Handbook of Theology Buku Pengantar Teologi. SAAT.

[56] Millard J. Erickson. (2003). Teologi Kristen Volume II. Gandum mas.

[57] Brian Baugus. (2005). Entrepreneurship in the Bible. Gandum mas.

[58] Yakob Tomatala. (2010). Spiritual Entrepreneurship Anda Juga Bisa Menjadi Entrepreneur Rohani. YT Leadership Foundation.

[59] Richards, L. O. (2007). Pelayanan Kepada Anak-anak. Kalam Hidup.

[60] K. Bertens. (1996). Moral and civics education. Mc Graw-hill.

[61] Djarkawi. (2008). Pembentukan Kepribadian anak. Bumi Aksara.

[62] Simanjuntak, R. N. J. (2009). 9 Masalah Utama Remaja. Yayasan Peduli Konseling Indonesia.

[63] Hooper Cooper. (2005). Child and Adolescent Mental Health: Theory and Practice. Edward Arnold Ltd.

[64] Herrman. (2005). Promoting Mental Health: Concepts, Emerging Evidence, Practice. A Report of the WHO. World Health Organization.

[65] Santrock. (2011). Child Development 13th Edition. McGraw Hill.

[66] Iskandar. (2009). Metode Penelitian Pendidikan dan Sosial. Gaung Persada Press.

[67] Wongso, P. (2020). Theologia Penggembalaan. Seminar Alkitab Asia Tenggara.

[68] Yakub B. Subsada. (2000). Pastoral Konseling Jilid I. Gandum mas. 